\section{Investment by private land developer companies and postcolonial urban growth in Ruwa (Zimbabwe), 1986-2015}

\section{Terence Muzorewa \& Mark Nyandoro}

DOI: http://dx.doi.org/10.18820/2415-0495/trp74i1.5

Revised April 2019, Published 30 June 2019

The authors declared no conflict of interest for this title or article

\begin{abstract}
This article qualitatively analyses the role of private land developer companies' investment in postcolonial Zimbabwe's urban development, with special reference to Ruwa Town. This sprawling town is outstanding for involving private land developers in its growth and expansion. All postcolonial established towns had emerged out of Government's direct investment through the Growth Point policy. By contrast, Ruwa was peculiar, because it developed from a public-private partnership approach. The article argues that, in the absence of State financial capacity in the postcolonial era, developer companies played a crucial role in infrastructure development and facilitation of public amenities. Although the companies were important in spearheading the growth of the town, they sometimes failed to meet certain standards of quality in urban infrastructure development required by town planning authorities. Despite this shortcoming, the article finds that the companies were essentially the most appropriate vehicles of urban development in times of economic crisis in the country.
\end{abstract}

Keywords: Infrastructure development, postcolonial infrastructure development, private land developer companies, Ruwa, Zimbabwe

\section{BELEGGING DEUR PRIVAATLANDONTWIKKELAARSMAATSKAPPYE EN POSTKOLONIALE STEDELIKE GROEI IN RUWA (ZIMBABWE), 1986-2015}

Hierdieartikel analiseer die rol van private landontwikkelaarsmaatskappye se beleggings in postkoloniale Zimbabwe se stedelike ontwikkeling, met spesifieke verwysing na die dorp Ruwa. Die uitgestrekte dorp staan uit omdat private grondontwikkelaars in sy groei en uitbreiding betrek was. Alle postkoloniale gevestigde dorpe het ontstaan uit die regering se direkte belegging deur die groeipuntbeleid. Daarenteen was Ruwa uniek omdat dit ontwikkel het uit 'n openbare-private vennootskapsbenadering. Die artikel beweer dat ontwikkelaarsmaatskappye, in die afwesigheid van staatsfinansiële kapasiteit in die postkoloniale era, 'n belangrike rol gespeel het in die ontwikkeling van infrastruktuur en die fasilitering van openbare geriewe. Alhoewel die maatskappye belangrik was om die groei van die dorp te bevorder, het hulle soms nie sekere standaarde van gehalte in stedelike infrastruktuurontwikkeling wat deur stadsbeplanning beveel is, nagekom nie. Ten spyte van hierdie tekortkoming, bevind die artikel dat hierdie maatskappye op daardie stadium die mees geskikte 'voertuie' vir stedelike ontwikkeling in die land was.

Sleutelwoorde: Infrastruktuurontwikkeling, postkoloniale infrastruktuurontwikkeling, private grondontwikkelaarsmaatskappye, Ruwa, Zimbabwe
MATSETE KAPA PEHELETSO YA TJHELETE YA DIKHAMPANE TSA PORAEFETE TSA NTSHETSOPELE YA LEFATSHE LE KGOLO YA TOROPO KA MORA DINAKO TSA BOKOLONE RUWA (ZIMBABWE), 1986-2015

Atikele ena e lekola ka mokgwa wa boleng, seabo sa letsete kapa peheletso ya tjhelete ya dikhampane tsa poraefete tsa ntshetsopele ya lefatshe ntshetsopeleng ya toropo ya Zimbabwe ka mora dinako tsa bokolone, ka ho qoolla, re itshetlehile toropong ya Ruwa (Ruwa Town). Toropo ena e teteaneng e tswa pele ka ho kenya batho ba poraefete ba ntshetsang lefatshe pele kgolong le katolosong ya yona. Ditoropo tsohle tse entsweng ka mora nako ya bokolone di ile tsa hlaha ho tswa ho letsete kapa peheletsong ya tjhelete ya Mmuso ka tshebediso ya Growth Point Policy. Ka ho bontsha phapang, Ruwa e ne e ikgethile, ka lebaka la hore e hlahile/thehilwe ka mokgwa wa kopanelo ya setjhabaporaefete (public-private). Atikele ena e ngangisana ka hore, ho se be teng ha bokgoni ba mmuso ba ditjhelete (State financial capacity) ka dinako tsa ka mora bokolone, dikhampane tsa ntshetsopele di bapetse karolo ya bohlokwa ntshetsopeleng ya meralo ya motheo le ho nolofatseng ditshebeletso tsa batho. Le hoja dikhampane di ne di le bohlokwa bakeng sa ho etellapele kgolo ya toropo, ka nako tse ding di ne di hloleha ho fihlella maemo a itseng a boleng ntshetsopeleng ya meralo ya motheo toropong, e neng e batlwa ke bolaudi ba thero ya toropo. Ntle le ho hloleha hona, atikele ena e fumana hore dikhampane ka hohlehohle e ne e le disebediswa tse loketseng bakeng sa ntshetsopele ya toropo ka dinako tsa mathata a moruo naheng.

\section{INTRODUCTION}

Scholars who have written on urban development in Zimbabwe have generally viewed urban infrastructure development as a state or government function. Because of this, they have missed the role of Private Land Developer Companies (PLDCs) in rapidly growing towns. They have also missed the intricate links between the state and developer companies

Dr Terence (T.T.) Muzorewa, Lecturer, Department of Development Studies, Rural and Urban Development Research, Midlands State University, Harare Campus, 1 Kwame Street, Harare, Zimbabwe. Phone: +263 78212 3244, e-mail: <terencemuzorewa@gmail.com> ORCID: https://orcid. org/0000-0002-9103-7882

Dr Mark (M.) Nyandoro, Senior Lecturer, Economic History, University of Zimbabwe \& Extraordinary Professor Research, School of Basic Sciences, Subject Group History, Faculty of Humanities, North-West University (Vaal Triangle Campus), School of Social Sciences, Building 11B, Office 029 Vanderbijlpark, South Africa. Phone: +263 7790 73043, e-mail: <nyandoromark@gmail.com> ORCID: https://orcid.org/0000-0002-1716-0102 
leading to a not-so-intended public-private partnership. Literature by, for example, Moszoro and Krzyzanowsk (2011), Ding and Lichtenbery (2009) and Van Der Veen (2009) on PLDCs and their functions in terms of urban spaces has mainly focused on the role and efficacy of these non-state institutions in industrial and fastindustrialising societies' growth and expansion. Until 2015, the role that private sector companies and their investment played in developing urban land for residential and commercial purposes was significant, given the difficult economic circumstances prevalent in Zimbabwe during this period (Nyandoro \& Muzorewa, 2017: 8). In general, the State in no partnership with private sector companies was instrumental in aiding town growth in a number of areas in Zimbabwe. However, the country's first specific experience with developer companies taking a leading corporate role in the emergence of a town, born out of the ashes of a defunct growth point, only manifested itself in the Ruwa case.

The article investigates the role of PLDCs in the development of Ruwa Town in Zimbabwe. It assesses the contribution of these institutions to the infrastructure development and expansion of the local economy of Ruwa since its inception in 1986. PLDCs were a unique case of non-direct government investment in postcolonial urban growth in the country. This article shows that postcolonial small town growth in Zimbabwe is not a homogeneous, but rather a heterogeneous and contested process that involves numerous town developer actors. These private developer players in Ruwa (a town located in the East of the capital, Harare) operated as autonomous units who, however, interacted with the government mostly at the infrastructure development level, not necessarily at the spatial planning level. The government did not purposely intend to have this interaction, but the lack of capacity and funds in a country experiencing myriad economic hardships since the 1990s stimulated it. The uniqueness of Ruwa Town development indicates how modern urban development was achievable in Zimbabwe based on a total different experience.

The article articulates how a growth point, initially rendered defunct, was then reorganised into a flourishing post-independence fast-growing town following an influx of residents from the rural areas and from nearby major metropolitan centres such as Harare.

\section{LITERATURE REVIEW}

In order to understand urban development in Ruwa, Zimbabwe, it is important to introduce the theory on partnership included in this study. The existing theory focuses on PLDCs, public-private partnerships (PPPs), bilateral partnership and the Regional, Town and Country Planning Act (1976) as the base for a partnership.

\subsection{Urban development in Ruwa, Zimbabwe}

The unremitting economic crisis in Zimbabwe (with the effect of hindering industrialisation) has demonstrated not only the lack of state and urban authorities' capacity to finance urban growth, but also the centrality of nonstate institutions in the country to facilitate the development of urban infrastructure and public amenities in sprawling towns.

Ever-changing rural and quasiurban authorities managed various services in the period up to 1986 , but service provision generally remained in shambles. There was a need for improved services by the growing numbers of people moving in from Harare and different parts of the country to settle there after independence (Nyandoro \& Muzorewa, 2017: 6). Residents of the area mainly hoped that independence would rapidly transform towns such as Ruwa from a rural to an urban settlement. However, this did not happen as fast as anticipated, due to the economic crisis besetting Zimbabwe in the early 1980s - a crisis exacerbated by the introduction of the Economic Structural Adjustment Programme (ESAP) in the early 1990s (Mlambo, 1997) and the controversial land reforms of 2000. The government and the emerging urban administrations, on their own, were financially constrained during ESAP (1990/1991-1995) to put up infrastructure in the form of roads, sewerage and water systems, electricity facilities, educational institutions and health facilities, which was commensurate with a rapidly urbanising area. The government-run Ruwa Local Authority or Ruwa Local Board (RLB), therefore, in a top-up type of land access for development, invited PLDCs to create a partnership in service provision and town development. The developers owned $99 \%$ of the 3188 ha of land available for development in the area and had better financial resources (Ruwa Town Council, 2011: 7). These private sector companies responded positively to the call as they were in the business of buying, developing and selling land. As a result, between 1987 and 2015, there were nine major and active developers operating in Ruwa. These were Mashonaland Holdings Private Limited, Chipukutu Properties, Zimbabwe Reinsurance Corporation (ZIMRE), Wentspring Investments Private Limited, Damofalls Investments Land Developers, Fairview Land Developers, Zimbabwe Housing Company, Barochit Property Developers, and Tawona Gardens Private Limited.

\subsection{Private land developer companies (PLDCs)}

PLDCs, also referred to as developers, are companies that subdivide land, which they own or purchase from individual private owners, into urban residential plots for the purpose of making a profit (Chirisa, 2013: 113). PLDCs are responsible for advancing the process of urbanisation worldwide. Van Der Veen (2009) illustrates how major western cities such as London, New York and Amsterdam have involved private developers in their growth and renewal processes. In Britain, the companies were popularised by Margaret Thatcher during her reign as Prime Minister, while President Ronald Reagan made them popular in the United 
States of America (USA) for providing housing and urban infrastructure (Mifaftab, 2004: 90). In the East, China and Russia also employed PLDCs in building essential infrastructure and expanding their cities (Wei, Taubenbock \& Blaschke, 2017: 32; Ding \& Lichtenberg, 2009: 1). In most cases worldwide, development organisations employed PLDCs to expand and renew towns and cities that were already established, but in Ruwa, these companies took a leading role in shaping the built environment from the inception of the town until 2015.

In Zimbabwe, PLDCs operated within the context of urbanisation and land markets. Marongwe, Mukoto and Chatiza (2011: 11-12) analysed urban markets in the country, defining them as the platform for interaction among land buyers, land developers and retailers, as well as the process of registration of land and property. They are part of the framework that governs planning and land administration in the country. In examining the situation facing different land developers in the urban land market in Zimbabwe, Marongwe et al. (2011: 12) contend that most of the companies' economic and policy challenges emanated from the economic crisis facing the country post-1980.

\subsection{Public-private partnerships (PPPs)}

Moszoro and Krzyzanowsk (2011: 3) examine broad public-private partnerships and the theory underpinning them. In their work, they view PPP institutions' operations as closely linked to PLDCs, and PPPs as "cooperation agreements between a public authority and the private sector to provide public service". These scholars provide the background of the theory and the risks involved in using the PPP approach in urban development and public service delivery. According to Moszoro and Krzyzanowsk (2011: 3), governments must be cautious of the tendency by private entities to take total control of public projects. Hence, they urge governments to set clear and unambiguous principles in their contracts with PLDCs in order to avoid the domination of these for-profit private partners. The work of these scholars clarifies the partnership theory, and their ideas have partly influenced the analysis of the nature of the partnership that emerged in Zimbabwe between the Ruwa local authorities and PLDCs.

\subsection{Bilateral partnership}

Since Ruwa is a new town developed during the independence era, there is hardly any literature on it compared to big cities such as Harare and Bulawayo. In a D.Phil. study on Ruwa, Chirisa (2013: 46-47) uses the stewardship theory and the partnership model as major concepts to guide his analysis on housing and infrastructure delivery. Merging stewardship theory and the partnership model, he came up with what he calls 'institutional pluralism', which he defines as "the cooperation of the government and civic society groups including the private sector, community and non-governmental organisations" in providing urban infrastructure (Chirisa, 2013: 2). His thesis calls for the creation of a forum for institutions to collaborate for the general good of citizens in housing provision (Chirisa, 2013: 39).

Unlike Chirisa's institutional pluralism, this article focuses on the bilateral partnership between Ruwa local authorities and PLDCs. While the article examines Ruwa's experience with PLDCs taking a leading role in the emergence of a town, it also shows (using qualitative approaches) the companies' differential impact on town development and the importance in Ruwa of imbedding the partnership theory or approach to urban studies. The Regional, Town and Country Planning Act of 1976 provided the most solid foundation of a partnership in Ruwa.

\subsection{The Regional, Town and Country Planning Act (1976): The basis for a partnership}

The Regional, Town and Country Planning Act (RTCPA) of 1976 required one to have a development permit in order to develop land. The development permit was the primary document establishing a legal partnership between PLDCs and local authorities in Ruwa and contained conditions and guidelines for the developer. The RTCPA was a step taken by the government of Zimbabwe to create regulations for housing, sanitation, transportation (road) and industrial infrastructure development under the Ruwa Development Plan of 1996 (Ruwa Town Council, 2011: 2).

As stipulated by the Act, no development involving the change of land use and intensity of infrastructure building was allowed without a development permit (National Archives of Zimbabwe 38971, 1995). Before any construction or development commenced, PLDCs were, therefore, obliged to apply for a development permit to the Department of Physical Planning of the Ministry of Local Government. The Department of Physical Planning worked with local planning authorities to draft the permit and to authorise permit applicants to start work. This then marked the evolution and consolidation of a collaborative process demonstrating the involvement of multiple stakeholders.

In order to achieve common objectives, the various stakeholders mobilised by the State and the local government-run town council to interact and negotiate horizontally, actively involved the urban planning authorities in the permit process (Follador, Duarte \& Carrier, 2018: 1; Nyandoro \& Muzorewa, 2017: 3). Involving the Ruwa planning authorities in making decisions on permit applications gave the Council a sense of ownership of the infrastructure development projects applied for by developers in a country not historically known for such collaboration between multiple social actors, councils and the State. However, such ownership was nominal, as the Council lacked direct control of the activities of the land developers except through granting the permit (for which they 
were the custodians) and exacting endowment payments from the developers. This, in some way, constituted a modicum model for private land developers to have a measure of control over land in the post-colony in Zimbabwe.

The RTCPA clearly stipulated that applicants for land subdivision for development purposes should set aside land for public amenities. It, thus, made it mandatory for PLDCs to set aside land for their construction (Government of Zimbabwe, 1996). After granting the land permit to a PLDC, it became the duty of the local planning authority to monitor the development activities of the developer company. Once issued, the permit was valid for between 12 and 24 months depending on the scale of the land development project applied for (Government of Zimbabwe, 1996). Development permits offered to PLDCs show that most of the projects undertaken by the developers in Ruwa ranged in size from 25 to 600 hectares. The primary role of the companies derived from the new and astute town planning that replaced the old piecemeal or ad hoc planning.

\section{STUDY AREA}

\subsection{Development background of Ruwa town}

Situated $23 \mathrm{~km}$ from the capital city of Zimbabwe, Harare's central business district (CBD), Ruwa town is a postcolonial established town (see Figure 1 for location of Ruwa in Zimbabwe). The town was founded on a White commercial farming area, which existed under the Bromley Ruwa Rural Council (BRRC) in the now Goromonzi District of Mashonaland East Province. Ruwa was established in 1890 as a farming area and its first local administrative authority, the BRRC, was set up in 1950 (Muzorewa, 2017: 15). In 1980, when Zimbabwe became independent, the BRRC changed its name to the Goromonzi Rural District Council, and the area assumed growth point status in 1986 (Muzorewa, 2017: 15). Operating as a growth point from 1986 to 1990 ,

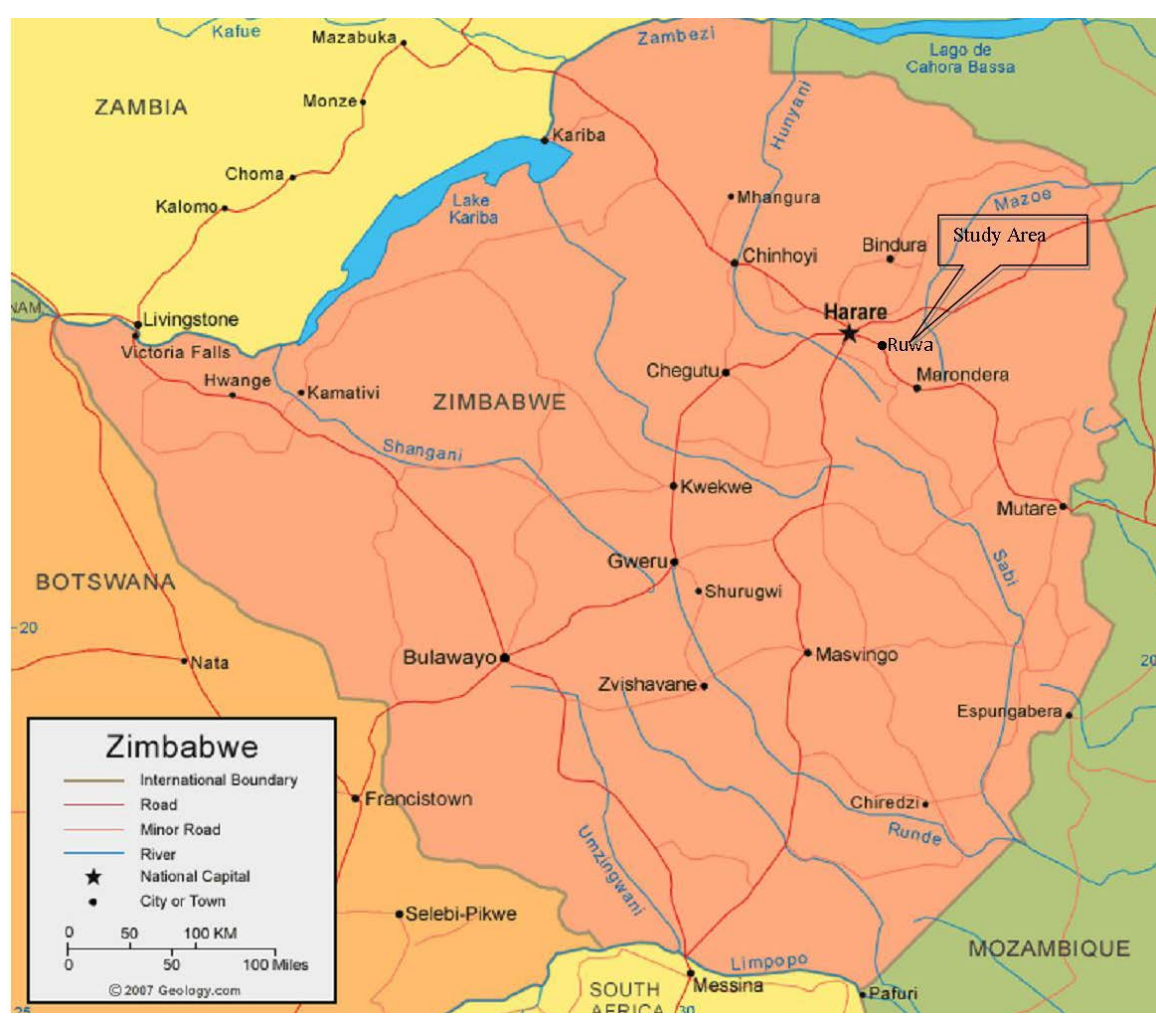

Figure 1: Map of Zimbabwe showing Ruwa

Source: Department of Surveyor General, Harare, 2013

Table 1: Urban populations of Ruwa and other towns in Zimbabwe, 1982-2012

\begin{tabular}{|c|c|c|c|c|c|}
\hline City & 1982 Census & 1992 Census & 2002 Census & 2012 Census & $\begin{array}{l}\text { 2002-2012 growth } \\
\text { percentage }\end{array}$ \\
\hline Harare & 656011 & 1189103 & 1444534 & 1485231 & 0.28 \\
\hline Bulawayo & 413814 & 621742 & 676784 & 653337 & -0.35 \\
\hline Chitungwiza & 172556 & 274912 & 321782 & 356840 & 10.9 \\
\hline Mutare & 69621 & 131367 & 170106 & 187621 & 10.3 \\
\hline Epworth & & & 114067 & 167462 & 46.8 \\
\hline Gweru & 78918 & 128037 & 141260 & 157865 & 11.8 \\
\hline Kwekwe & 47607 & 75425 & 93072 & 100900 & 8.4 \\
\hline Kadoma & 44613 & 67750 & 76117 & 92469 & 21.4 \\
\hline Masvingo & 30523 & 51743 & 69993 & 87866 & 25.5 \\
\hline Chinhoi & 24322 & 43054 & 56794 & 77929 & 37.2 \\
\hline Norton & & 20405 & 44397 & 67591 & 52.2 \\
\hline Marondera & 19971 & 39384 & 52283 & 61998 & 18.6 \\
\hline Ruwa & & 01447 & 23689 & 56678 & 139.3 \\
\hline Chegutu & 19606 & 30191 & 43424 & 50255 & 15.7 \\
\hline Zvishavane & 20597 & 32984 & 35128 & 45230 & 28.8 \\
\hline Bindura & 18243 & 21167 & 33637 & 42861 & 27.4 \\
\hline Beitbridge & & 11596 & 22136 & 41767 & 88.7 \\
\hline Redcliff & 22109 & 29959 & 32417 & 35904 & 10.8 \\
\hline $\begin{array}{l}\text { Victoria } \\
\text { Falls }\end{array}$ & 8126 & 16826 & 31519 & 33660 & 6.6 \\
\hline Rusape & 8216 & 13920 & 22741 & 30316 & 33.3 \\
\hline Chiredzi & 10257 & 21116 & 25849 & 30197 & 16.8 \\
\hline Kariba & 12364 & 20736 & 22726 & 26112 & 16.4 \\
\hline Karoi & 8748 & 14763 & 22383 & 26009 & 16.2 \\
\hline Chipinge & 6077 & 11582 & 16539 & 25214 & 52.5 \\
\hline Gokwe & & 7418 & 17703 & 23906 & 35.0 \\
\hline
\end{tabular}

Source: Central Statistical Office, Population Unit, Harare, 2014 
Ruwa became an urban area under the administration of the Ruwa Local Board (RLB) set up in September 1990 (Ruwa Town Council, 2011: 6). It was subsequently granted town status and effectively weaned from metropolitan Harare in 2008, with the Ruwa Town Council (RTC) given the role to administer the town.

It only took two decades for Ruwa to develop from a rural growth point to a town. It was the fastest growing town in the country between 2002 and 2012, which was characterised by an economic meltdown. Table 1 shows the population growth of Ruwa vis-à-vis other towns.

Table 1 illustrates population growth in percentage terms of all major towns in Zimbabwe between 1982 and 2012. The last census in Zimbabwe was held in 2012. A comparison of the population growth rates of the towns shows that Ruwa's growth was exceptional. However, before the developer companies-Council-partnership, Ruwa did not have an urban infrastructure, because it still existed as a commercial farming area, as illustrated in Figure 2.

Figure 2 shows Ruwa in 1980 before the intervention of PLDCs in the development process of the town. The area was a commercial farming area with some supporting infrastructure for farming ventures.

\section{METHODOLOGY}

In assessing the role played by the developers in the growth of Ruwa, the article uses primary and secondary sources to derive research data. Primary data was mainly derived from interviews chiefly based on purposive sampling targeting Ruwa residents, PLDCs' personnel and workers of the Ruwa Council. The Ruwa Town Repository or Archive was a main source of primary data. Secondary sources (journals, books, articles, and newspapers) were useful in situating the Ruwa case within broader urban studies in Zimbabwe and the world at large.

\subsection{Town planning in Ruwa and its interface with private sector companies}

The early stages of Ruwa's development were characterised by ad hoc or piecemeal planning. This methodology of planning involves the use of a number of independent and different micro-layout plans (Chigara, Magwaro-Ndiweni, Mudzengerere \& Ncube, 2013: 32). Such type of planning has been associated with a myriad of weaknesses that include lack of harmony in land use, uncoordinated developments in sprawling environments, and disorderliness. In Zimbabwe, piecemeal planning was a result of the incapacity of small towns to develop both local development plans and master plans (Chigara et al., 2013: 32). Generating or creating local development plans involved consultation with land surveyors. This was a cumbersome process for small towns such as Ruwa with limited technical staff and financial resources. In Ruwa, using piecemeal planning, every PLDC prepared a plan or diagram showing the subdivision of the land to be developed. Because the plans were prepared in isolation and in different periods, this resulted in duplication of zoning of land use or services in adjacent or neighbouring development projects.

In the aftermath of these developments, being the first urban local authority responsible for Ruwa, in 1990, the Ruwa Local Board discovered that the area had been characterised by incremental and ad hoc subdivision of private land without an overall planning document in place. Therefore, the RLB started to prepare the Ruwa Local Development Plan (LDP) with the aim of harmonising development and stopping piecemeal planning by adopting formal planning in the development of the town. The preparation of the first draft of the LDP took place from 1991 to 1996 , but it was only approved in 2000 (Muzorewa, 2017: 108). This was rather too late to rectify the damage caused by piecemeal planning, since some PLDCs had already received their land development permits, with others already engaged in developing the areas allocated to them.

Notwithstanding these challenges, PLDCs' planning resulted in the development of more residential areas than any other land scheme in Ruwa and most of the residential

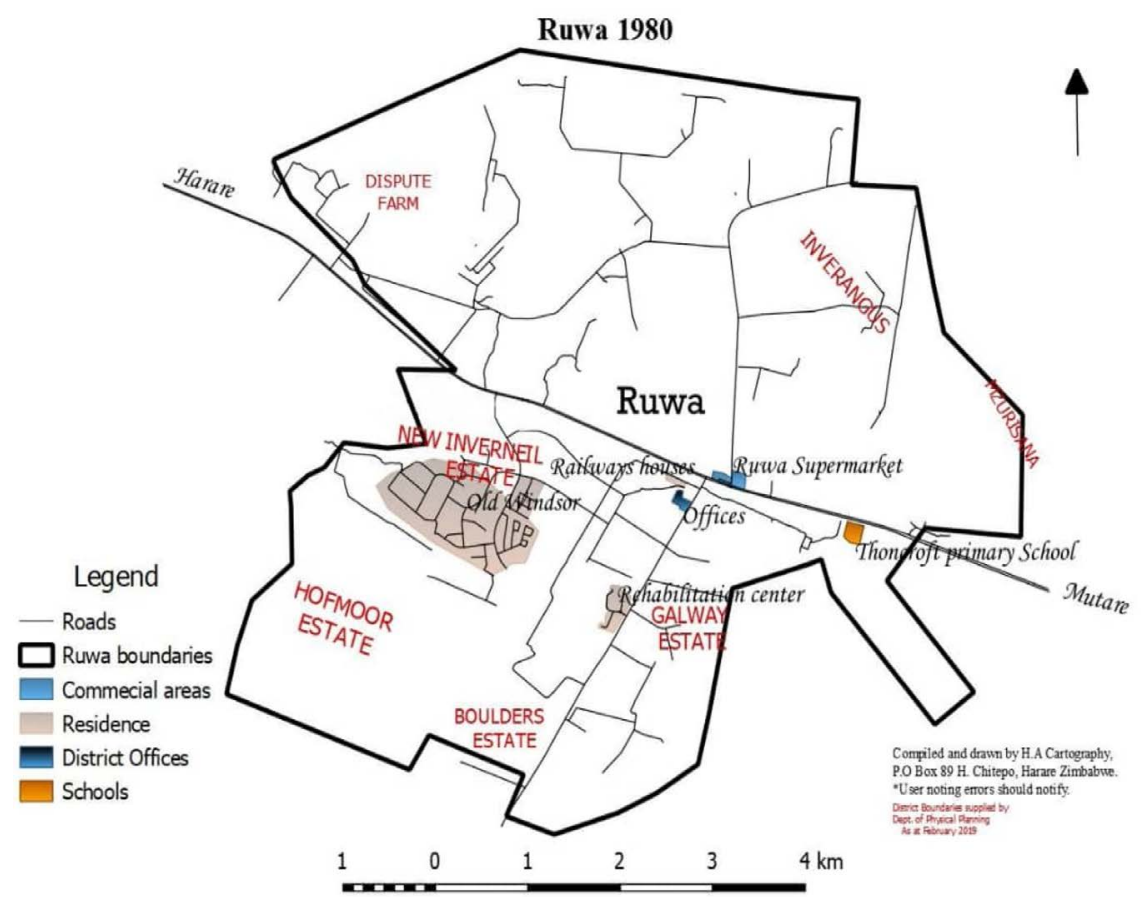

Figure 2: Ruwa in 1980

Source: H.A. Cartography, 2019 
plots were sold to people who were working in Harare and Chitungwiza. The number of residential areas in Ruwa outgrew the industrial parks, thereby causing a degree of partial dependency for jobs and services on Harare. This was because, generally, Zimbabwe was facing an economic crisis of major proportions between 2000 and 2008 that led to the collapse of the manufacturing industry. However, despite the collapse of industries, housing continued to be a necessity among people in the country, causing a high demand for residential plots, but a low demand for industrial plots.

\subsection{Contribution of private land developer companies in the growth of Ruwa, 1986-2015}

PLDCs made significant contributions in various areas of town development that included the development of residential, commercial and industrial areas (Ruwa Town Council, 2011: 4). The companies were responsible for the construction of on-site, off-site and public infrastructure in the town. In Ruwa, land was mainly privately owned and from the attainment of growth point status in 1986, many private landowners resorted to subdividing their land for the purposes of urban development (Chirisa, 2013: 18). The Ruwa Local Council Board had assigned every PLDC a specific area to develop. After receiving development permits granted under the auspices of the RTCPA, the PLDCs commenced their land development projects in Ruwa and were influential in the development of both industrial sites and lowincome housing infrastructure that greatly stimulated the process of urbanisation (The Herald, 2007: 6).

\subsection{PLDCs and the establishment of manufacturing industries in Ruwa}

PLDCs such as Mashonaland Holdings and Damofalls immensely contributed to industrial development, with the former playing a leading role in developing infrastructure and subsequently handing it over to the Ruwa Council in a process, which began in 1996 , a year after the abandonment of ESAP (The Herald, 2007: 6). They serviced the town with roads, residential and industrial plots, and other infrastructure between the late 1980s and 1990 when the Zimbabwe economy was still relatively stable (see Figure 3).

In the early 1990s, the well-serviced industrial plots attracted a number of companies to operate in the town (Muzorewa, 2017: 133). Odero (2003: 5) notes that the well-serviced industrial plots and the building of a water pump station by this developer effectively reduced the cost of industrial investments to prospective investors, thereby attracting industries to the area. The serviced plots, for instance, attracted industrial companies such as AgricAfrica to relocate from Harare to Ruwa, because the cost of investing in new industrial plants and off-site infrastructure by PLD investors was $50 \%$ lower compared to Harare (Odero, 2003: 4). The serviced Mashonaland Holdings plots in Ruwa mainly resulted in the establishment of the 120 industrial companies that employed over 7000 people by the mid-1990s (The Herald, 2007: 6).
Although Damofalls established fewer industries than Mashonaland Holdings, it established a thriving industrial area housing 23 manufacturing industries. However, by the end of 2015, the Damofalls industrial site was not fully functional, because it was developed in the mid-2000s, a period when the nation at large was facing economic turmoil. The economic crisis facing the nation retarded industrial growth in the country, in general, and in Ruwa, in particular. On the whole, the post-2000 economic crisis in Zimbabwe meant that, by 2015, Ruwa's industrial area only housed 205 industries.

Figure 3 is a satellite view of the Ruwa industrial area developed by Mashonaland Holdings. It gives a good view of the road network providing easy access to every industrial plant.

\subsection{PLDCs and the establishment of low-cost housing in Ruwa}

Apart from establishing industrial complexes, PLDCs played a crucial role in the development of high-density, low-cost housing and medium-density suburbs that

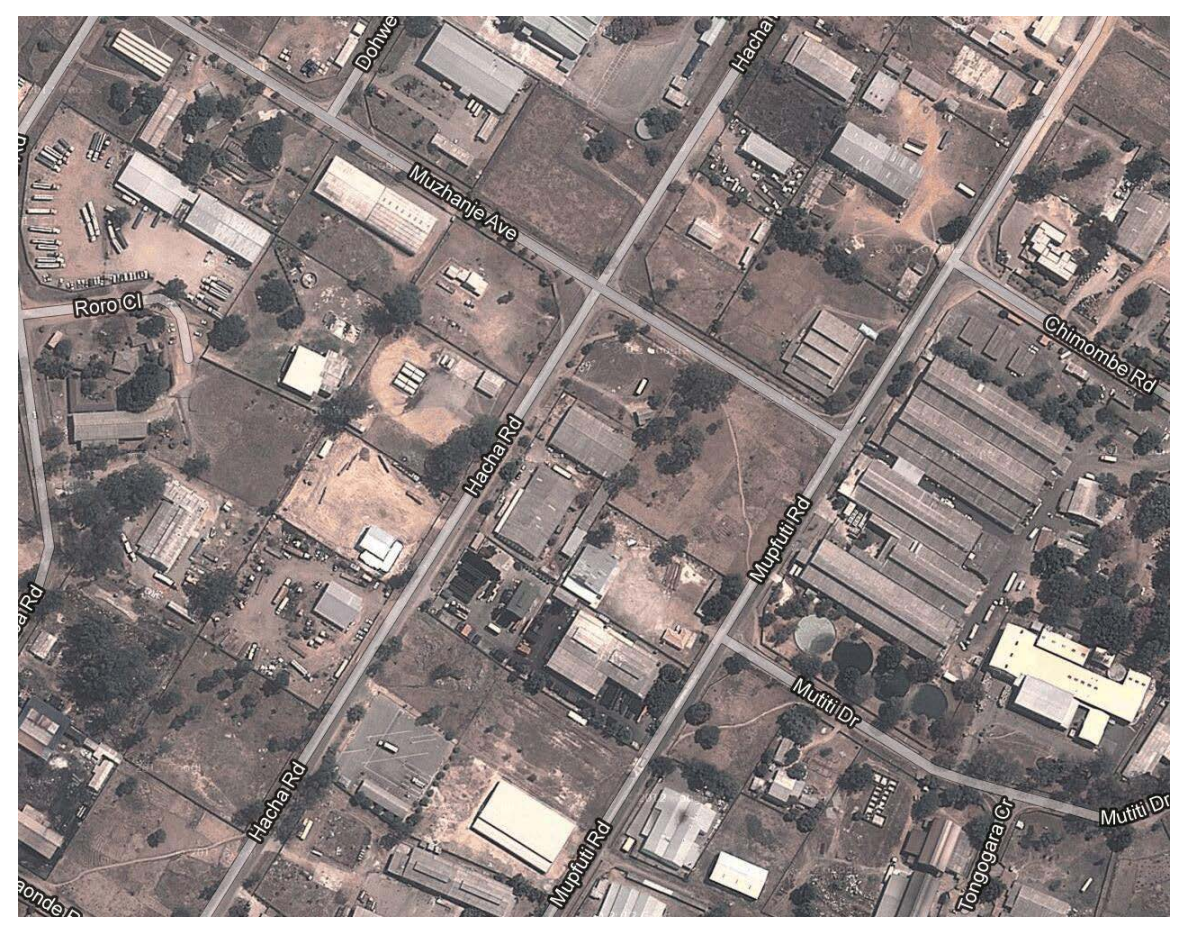

Figure 3: Ruwa industrial area satellite picture

Source: $\quad$ Picture by T.T. Muzorewa using Google Earth, April 2012 
generated some employment that partly cushioned some construction workers from the effects of the ESAP and immediate post-ESAP eras. Because of the prominent role performed by the private developers, the naming of most of the suburbs in Ruwa after the companies that developed them became common. The first company to establish a residential suburb was Mashonaland Holdings (see Figure 4). A number of companies followed Mashonaland Holdings' example. These include Chipukutu Properties, responsible for developing Chipukutu Park, and the Zimbabwe Reinsurance Corporation (ZIMRE) which developed ZIMRE Park. In addition, ZB Bank/Wentspring Investments Private Limited developed Springvale Park; Damofalls Investments Land Developers developed Damofalls Park; Fairview Land Developers developed Fairview Park; the Zimbabwe Housing Company developed Cranbrook Park; Barochit Property Developers developed Barochit Park, and Tawona Gardens Private Limited developed both the Tawona Gardens high-density suburb and Marcus Park. The emergence of these relatively low-cost residential areas near Harare was of immense benefit to many property-seeking people in a time of economic crisis.

The development of high- and medium-density suburbs, in particular, benefited the low- and medium-income earning groups in Ruwa and other surrounding places such as Chitungwiza, Goromonzi and Harare. The Ruwa Local Authority tried to ensure that the low-income earning groups benefited first by giving them preference over plots and built housing in every highdensity suburb. The Local Authority did this by recommending people employed in Ruwa and those on the Council housing waiting list to be prioritised by the PLDCs in the allocation of plots and houses. The Ruwa housing waiting list is a list of local home seekers who paid annual subscriptions to be top priority beneficiaries of low-cost housing. Because Ruwa mainly comprised local low-income home seekers, some PLDCs went out of their way to provide affordable housing loans of more than USD 30000 to their clients in 2009 when the Zimbabwean economy became relatively stable under the Government of National Unity (Chirisa, 2013: 213). A case in point was ZB Financial Holdings that, from 2009 to 2012, gave loans to 394 clients to buy high-density plots and construct houses in Springvale Park. The development resulted in the provision of much-needed shelter for lower income inhabitants of the town in a manner synonymous with the case of Houston, Texas in the USA (King \& Lowe, 2018).

The harsh economic conditions following ESAP, but cheaper land prices of USD 10 per $\mathrm{m}^{2}$ motivated settlement in Ruwa post-1996. The end of ESAP until the 2000s witnessed many people moving/ relocating from Harare to Ruwa, as the latter offered affordable housing compared to the capital city (Odero, 2003: 4). Economic inflation, which increased with the land invasions of 2000 , reached alarmingly hyper levels of $79600000000 \%$ per annum by 2008 . Inflation motivated brisk business in the buying of land perceived to be cheap on the low-income market.
In an interview on 10 June 2014, Albert Paulo (a land development officer) noted that 450-square metre plots in Fairview, which were available after the hyper-inflation period, were sold in 2009 for only USD 8500 . This was relatively affordable for some low-income earners and led to the development of approximately 6000 properties by PLDCs (Muzorewa, 2017: 108).

However, the development of high- and medium-density suburbs by PLDCs had intrinsic problems. PLDCs found the selling of residential plots in high-density suburbs so profitable that this affected the development of other important land-use schemes such as industrial and commercial. The development of Cranbrook Park is an example of a situation where a high-density suburb was prioritised over the establishment of an industrial area. In the Ruwa Development Plan, Cranbrook farm had been zoned for industrial plot development, but the plan was changed to a residential one after the developer realised the dire need for plots for the low-income earners compared to industrial facilities (Palmer Associates Private Limited, 1996: 2). However, changing the Local Development Plan left

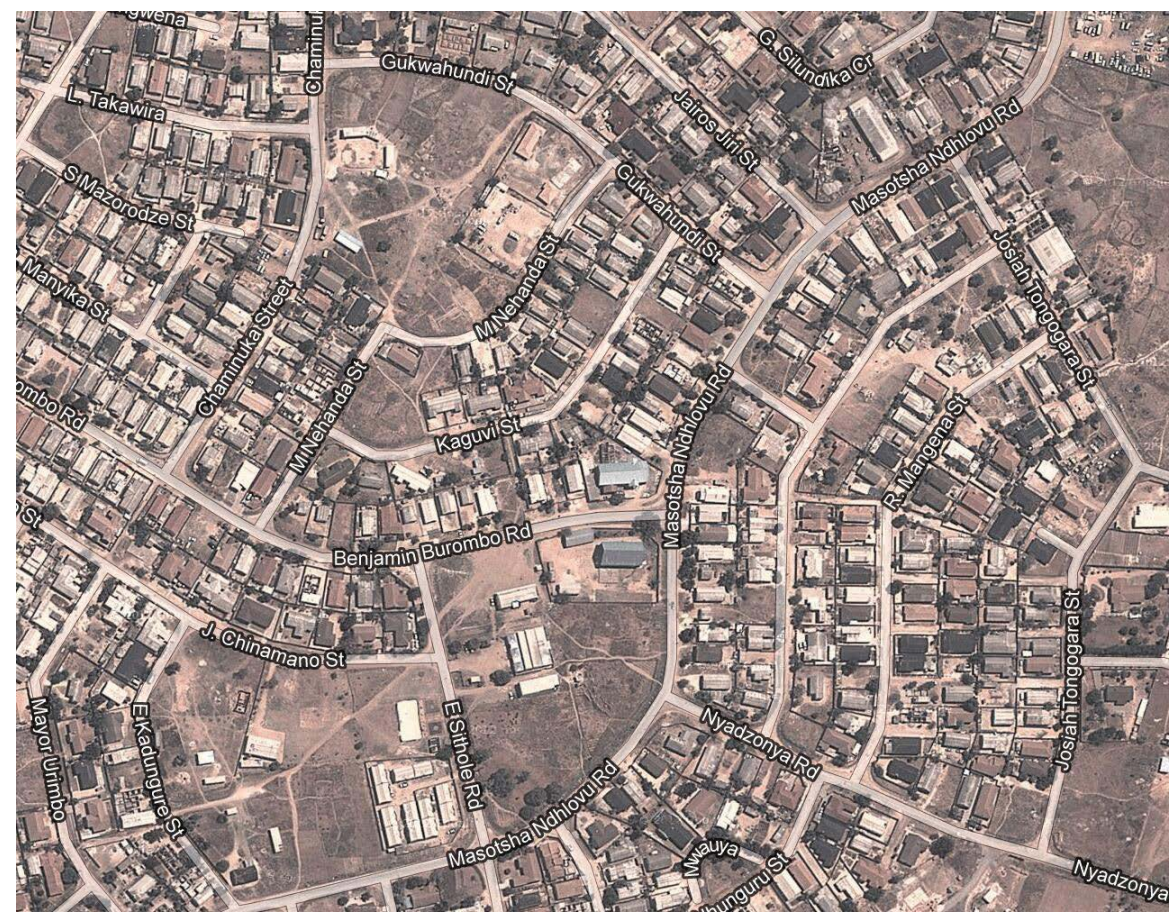

Figure 4: Ruwa location medium-/high-density residential park

Source: $\quad$ Picture by T.T. Muzorewa using Google Earth, April 2012 
the town with less land for the expansion of manufacturing industry.

Figure 4 is a satellite view of Ruwa location residential suburb. The picture shows the southern part of the suburb, which is a medium-/ high-density residential area. Medium- to high-density suburbs were prioritised over industrial sites, as illustrated in Figure 5.

Figure 5 shows how Ruwa had developed by 2015. In only three decades from 1986, the PLDCs developed Ruwa from a commercial rural farming area to an urban centre. This map of spatial development in Ruwa illuminates different land uses and zoning of the industrial and residential areas.

\subsection{The development of public recreational and social amenities in Ruwa: A PLDC responsibility}

PLDCs played a leading role in the development of public and social amenities in Ruwa, as they left open spaces for public recreational purposes. Sporting activities such as tennis, rugby, golf, cricket, hockey, basketball and swimming, regarded as European and affluent people's sports, were hitherto not culturally common among African communities (Cheater, 1986: 133). Recreational and sporting facilities were thus created considering that the larger part of the African population in Ruwa was not interested in them. Culturally, the Ruwa community was quite interested in soccer (football) and this influenced the private company-led development of soccer facilities in the town. This is why, in the Ruwa location, four residential park plots were turned into a vast sporting field used by residents for various sporting and cultural activities such as soccer, netball and traditional dance groups (Ruwa Town Council, 1996b: 2). PLDCs, therefore, provided an essential service and played an important role in establishing sporting arenas, which were part of public recreational facilities in the town.

In addition to recreational facilities, the companies also provided additional land for the construction of community amenities such as churches and beer halls. In Zimre Park, the developer reserved land for a beer garden, a tavern and a community beer hall (Ruwa Town Council, 2006a). Mashonaland Holdings also constructed Mavambo Beer Hall (Ruwa Town Council, 2006a). Religious denominations such as the Anglican Church, the United Methodist, the Methodist Church in Zimbabwe, the Seventh Day Adventist, His People Ministries, the Salvation Army and Maranatha benefited from the land that Mashonaland Holdings reserved for community purposes (Ruwa Town Council, 2011: 12). There were, for instance, eight church plots reserved for faith-based organisations in the Damofalls area and all of the plots were occupied by the end of 2001 (Ruwa Town Council, 2001a). In all the suburbs, at least one plot was reserved for a church. Churches catered for the religious, spiritual and social needs of the community. Nearly every member of a household in the Ruwa community went to church (Muzorewa, 2007: 120), and PLDCs played a huge role in providing such cherished facilities.

\subsection{The development of educational and health facilities in Ruwa: A PLDC responsibility}

The developer companies also facilitated the establishment of educational institutions in Ruwa. Colonial urban development was characterised by State monopoly in the development of pro-White educational facilities. White schools, the so-called Group A schools, were relatively well equipped with state-of-the-art classrooms and sporting amenities. In Ruwa, Mashonaland Holdings was one of the first companies to develop a secondary school for Africans and provided land for the construction of Chiremba Primary School for African pupils. In 1997, the PLDC (Mashonaland Holdings), through its subsidiary construction company, Club Construction, constructed the T C Hardy Secondary School (The Herald, 2007: 6). The school primarily served the low- and medium-income earning groups who constituted the majority of the residents of Ruwa location. From 1996 to 2000, the ZIMRE developer company reserved land for the establishment of two primary schools, a secondary school and

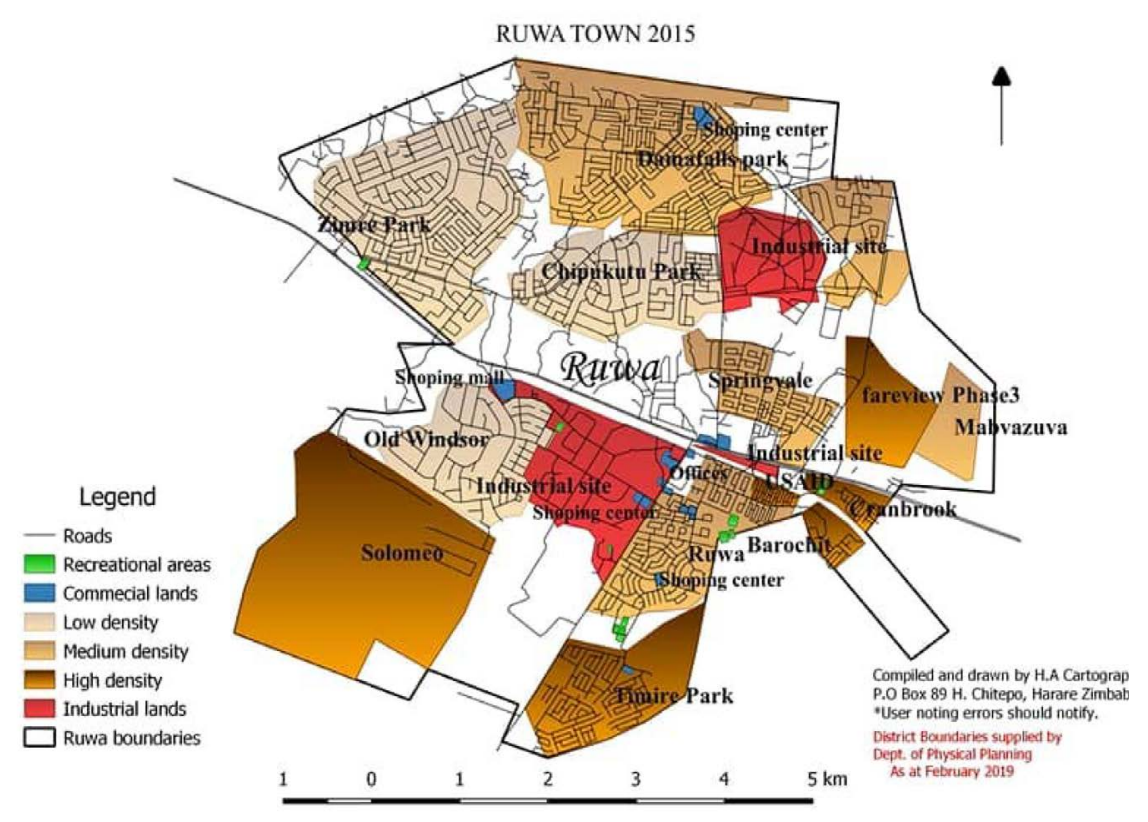

Figure 5: Ruwa in 2015

Source: H.A. Cartography, 2019 
a number of crèches, pre-schools or Early Childhood Development Centres (ECDCs) in Zimre Park. ZIMRE discounted the RLB 23\% for the purchase of three school sites (Ruwa Town Council, 2006a). This prevented private investors such as Winwood from taking over land reserved for school development. In Chipukutu Park, the private land developer provided land for the establishment of a primary school and two crèches (Ruwa Town Council, 2004: 2). In 2001, when development of Damofalls Park started, the Damofalls PLDC, in an attempt to expand social services, facilitated the establishment of five primary schools and four plots for pre-school institutions (Ruwa Town Council, 2003a: 2). Land for school development was not easy for PLDCs to sell compared to residential plots which were in high demand. Therefore, the Ruwa local authorities ensured that the developer companies contributed towards school development by making it mandatory for PLDCs to set aside land for educational facilities. This helped avoid a shortage of schools in the town.

To cater for the health needs of the town, PLDCs further facilitated the establishment of health facilities such as clinics. In 1995, Mashonaland Holdings constructed a clinic in Ruwa location. According to Chidhakwa, the Ruwa Town Planner, in an interview on 5 June 2014, the clinic provided health services to residents from all low-income earning groups in the residential suburb. The clinic and polyclinics established by private developers had a bigger mandate, as they served a broad catchment. These health centres serviced not only Ruwa residents, but also the adjacent urban and peri-urban areas such as Epworth and Goromonzi.

\subsection{Installation of water development systems}

Apart from contributing towards the development of recreational, health and educational facilities, Ruwa PLDCs played an important part in the installation of water supply and water reticulation systems. In 2007 , PLDCs operating in the northern part of Ruwa joined in creating the Ruwa River Consortium (RRC) or water development syndicate. This consortium had a mandate of improving water infrastructure in the town. The members of the RRC included prominent PLDCs such as ZB Financial Holdings, Fairview Land Developers, Barochit Land Developers, and Tawona Gardens. To facilitate water provision to meet the rising demand, the RRC entered into a memorandum of understanding with the RLB in 2007 Town Council, 2006b). The water reservoir, measuring $6.8 \mathrm{~m}$ in height from its base, was constructed and elevated on Rambuko Ranch in Springvale (see Figure 6).

According to Bakaris, Director of Tawona Gardens, in an interview on 11 January 2015, the RRC is credited with constructing $60 \%$ of the main water system for the northern Ruwa suburbs, while the Local Authority put up the remainder of $40 \%$. After constructing the reservoir, the Consortium also established a water pumping station and other water reservoirs at the Chiremba Road and Harare-Mutare Road intersections (Muzorewa, 2017: 120). These reservoirs were part of the main water infrastructure financed by PLDCs, but owned by the Local Authority, and to construct a water reservoir (Ruwa

their construction underscored the Authority's long-standing partnership with private land developers (Nyandoro \& Muzorewa, 2017: 1-10). The amalgamation of PLDCs into a consortium that collaborated with the Local Authority played a crucial role in developing the water system in Ruwa.

PLDCs did not only work through consortiums in providing water infrastructure, but individual developers were involved in many different water infrastructure projects in the town. Damofalls Land Developers, for example, constructed a water treatment plant in Ventusburg, $74 \mathrm{~km}$ from Ruwa, to secure water supply for Damofalls Park. According to Mhiti, Financial Director of RTC, in an interview on 9 March 2012, the water plant not only supplied Damofalls Park, but also supplemented Ruwa Town's water supply from Harare City. Harare had served as the major water supplier for Ruwa since the town's inception as a growth point in 1986 (Nyandoro \& Muzorewa, 2017: 3). Because of the high population growth in the town, which reached over 25000 people in 1991 (Central Statistics, 2014), it was failing to meet the daily water requirements that were over $1900 \mathrm{~m}^{3}$ per day in 1990 after Ruwa was given urban status (Davison, 2005: 89). The granting of town status had effectively reclused

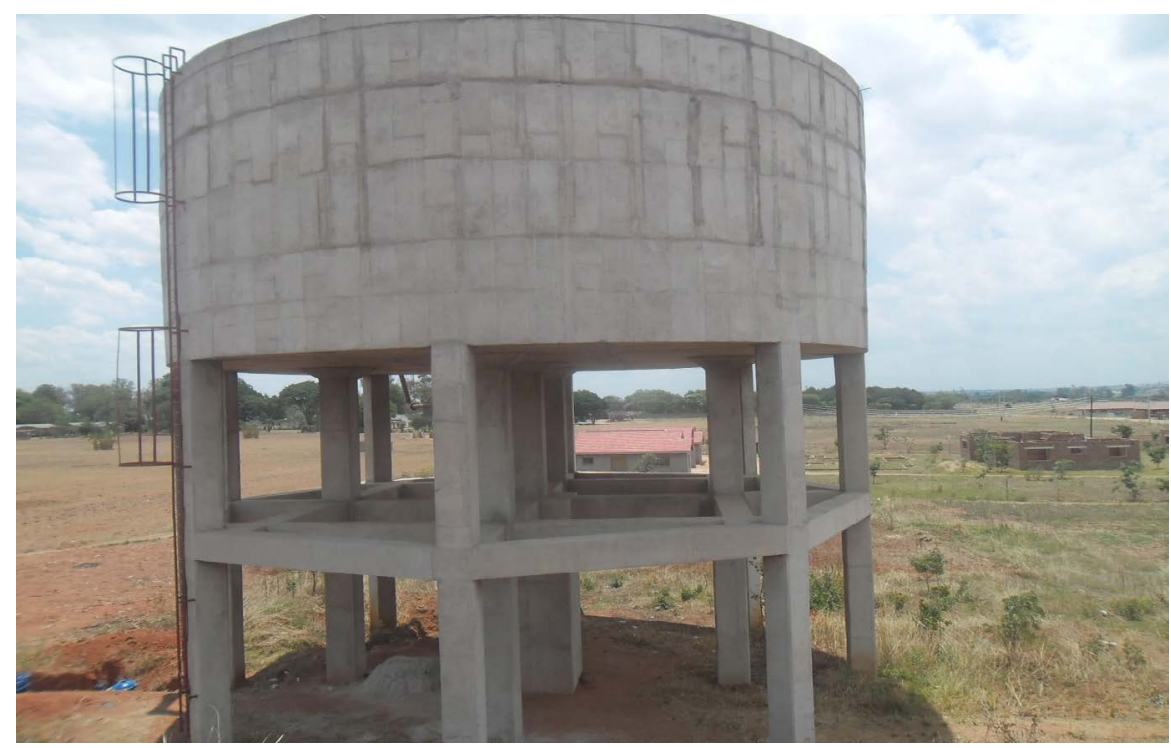

Figure 6: Water reservoir/tank in Springvale: An RRC venture

Source: Image by T.T. Muzorewa, 20 November 2014 
it from dependency or existing virtually as a 'foster child' of Harare.

The drilling of boreholes further boosted water from the treatment plant. PLDCs such as Mashonaland Holdings, Springvale and ZB also sank boreholes used as water supplements in times of water shortages, that is, when the Council failed to supply water (Chirisa, 2013: 232). Mashonaland Holdings Limited worked in partnership with the Town Council in sinking six boreholes near residential areas in the Ruwa location (Davison, 2005: 25). The boreholes became very important when the Council failed to provide clean tap water because of limited water sources for the Local Authority. Hence, whenever there were water shortages, people queued for water at the boreholes.

In addition to boreholes, sewerage systems were established. Each PLDC was responsible for the construction of sewerage systems as well as connecting the sewerage pipes to the main pipes owned by the Local Authority. Ruwa's main sewerage infrastructure was put in place by PLDCs as part of the terms of their permits (Muzorewa, 2017: 125; Nyandoro \& Muzorewa, 2017: 9). While the $\mathrm{RRC}$ constructed the main sewer system for the northern suburbs (Chirisa, 2013: 232), not all plots in Ruwa were serviced by piped sewerage systems. Some larger plots (over $1000 \mathrm{~m}^{2}$ ) especially in the low-density and industrial areas were serviced by septic tanks.

Some septic tanks in parts of Ruwa, nevertheless, posed pollution dangers to the Ruwa river that flows underneath suburbs such as Zimre Park. According to the Ruwa Town Planner, soil samples from Zimre Park proved that the soil type was sandy and loose. This soil allowed sewerage to contaminate the river. Sewerage contamination led the Local Authority to warn the ZIMRE developer company against the environmental danger of using septic tanks in some parts of Zimre Park, but the PLDC was determined to cut the cost of sewer piping by using septic tanks (Chirisa, 2013: 109). Ultimately, no action was taken against the developer, because ZIMRE received its permit in the early 1990s when there were no strict regulations for the protection of the environment in the country. Environmental issues were only seriously considered after the enactment of the Environment Management Act (Chapter 20: 17) of 2002, which established the Environment Management Agency (EMA) to oversee the sustainable management and protection of the environment (Nyandoro, 2018). Therefore, it can be noted that, although PLDCs played a vital role in the establishment of sewerage systems in Ruwa, they often did not consider environmental issues.

\subsection{Installation of road systems}

PLDCs constructed the road system in Ruwa town to improve transportation efficiency. Developer companies graded and tarred all roads in the Ruwa industrial area, Ruwa location, Chipukutu, Windsor, and Zimre Park. Nevertheless, in certain suburbs, some developers such as Fairview and Barochit did not finish the construction of roads, while others such as Damofalls were very slow in completing the road-construction process (Ruwa Town Council, 2006c: 4-5). The companies attributed their failure to complete the construction of road infrastructure and their slow pace to the fact that the residential plots they were supposed to service were sold during the national economic crisis, which was characterised by hyperinflation. In 2008, inflation reached a record daily rate of $98 \%$ (Economics Help, 2018). Inflation made it difficult for the developer companies to invest the proceeds from the sales of plots in road construction, because it eroded profits. However, inflation cannot vindicate them from their failure to put in place road infrastructure, since it was their mandate to do so, as required by the development permit and their contractual agreement with the RLB.

\subsection{Installation of electricity development systems}

Besides road construction, PLDCs were responsible for the installation of electricity supply infrastructure in Ruwa. Every industrial complex was connected to the electricity supply system, while most of the residential areas had electricity installed. The developers, through the government's utility company, the Zimbabwe Electricity Supply Authority (ZESA), installed electricity in the town. ZESA Holdings carried out the establishment of ZESA substations in the residential suburbs, while the developer financed the process (Muzorewa, 2017: 126). The power utility company carried out electricity installations and re-routed power lines. Damofalls Land Developers provided seven plots for the erection of ZESA substations (Ruwa Town Council, 2003b: 2). This marked an important phase in the installation of electricity by PLDCs in Ruwa, which greatly assisted the Local Authority.

\section{Although PLDCs were hailed for} electricity infrastructure, some suburbs lagged behind in terms of electricity installations just as in the construction of roads. An example can be given of Fairview Park where, in phases one and two of the development project, the installation process was incomplete, with only poles and wiring in place. There were no electricity transformers by 2015 (Muzorewa, 2017: 28). Notwithstanding this, PLDCs still had a role to improve service delivery, given a local economy that was not performing.

\subsection{Private land developers and the Ruwa local economy}

Apart from providing housing and public infrastructure, PLDCs were involved in improving the local economy through establishing some commercial areas and shopping malls in the town (see Figure 5). Mashonaland Holdings, for example, constructed a commercial centre to service both industrial and residential areas. In these areas, services such as banking, shopping facilities and market places for 
locally produced agricultural and industrial commodities were provided. Club Construction, a subsidiary of Mashonaland Holdings Company, built the Maha Shopping Centre, which housed restaurants, beer outlets, banks, and shops. The Ruwa community benefited from the business centre, which offered shopping facilities and tertiary services such as health surgeries and banking halls.

Damofalls Land Developers complemented the efforts of Mashonaland Holdings in providing public market places. In April 2000, these developers established a green market in Damofalls Residential Park for fruit and vegetable "vending". Fruit and vegetable "vending" came to characterise Damofalls Residential Park.

Fresh produce such as vegetables and fruits from farmers in Ruwa's agricultural hinterland was sold at the market. This reduced the farmers' transport costs usually incurred when delivering produce to the traditional Mbare Musika Market in Harare. The Green Market supported locals' livelihood. Most of the women, in particular, were "vendors" (informal traders).

As part of their contribution to the local economy, all PLDCs paid endowments to the Local Authority for property development in Ruwa. The endowments benefited the Council, as they constituted its land and revenue bases. One per cent of the land owned by the Local Authority was acquired through land development endowments from Mashonaland Holdings (Ruwa Town Council, 2011: 4). In Damofalls Park, the Damofalls Company gave part of the endowment to the RLB in the form of a plot (Ruwa Town Council, 2001b). Clearly, the Local Authority had no land prior to the involvement of the PLDCs in the town, as all the land was privately owned by these companies, after purchasing it from commercial farmers and individual plot holders in the area (Nyandoro \& Muzorewa, 2017: 5). Therefore, land endowments gave the Local Authority the opportunity to own land in Ruwa.
Some cash endowments were also given to the Council. The Council received an average of $10 \%$ from the proceeds of the sale of high-density suburbs by Mashonaland Holdings, ZIMRE and Chipukutu Properties (Ruwa Town Council, 1996a: C14). The endowment ranged between $7 \%$ and $13 \%$ (depending on the size of the plots) of the proceeds from the sales of the plots in the development scheme. The endowment fees paid by the PLDCs became a major revenue source for the Local Authority, and without money from endowments, the operations of the Local Authority were not viable.

To improve the aesthetic value of the area, PLDCs in Ruwa played an important role in protecting the natural environment - a concept that attracts investors. This is contrary to the view of the critics of the private-public partnership approach in urban development that the private sector does not consider the environment in the urbanisation process because of their greed for profit-making (Mifaftab, 2004: 93; Nyandoro and Muzorewa, 2017: 6). In Ruwa, the indigenous Musasa trees, preserved in most of the suburbs in open spaces, demarcated different land uses. The development of the plots in Springvale was undertaken after the developer received positive recommendation from the Environment Impact Management Report prepared by the Director-General of EMA (Ruwa Town Council, 2011: 2). The PLDC had, in fact, employed security guards to guard the Springvale area against the illegal extraction of pit and river sand by local builders (Chirisa, 2013: 232). In the process, ZB Financial Holdings (developers of Springvale residential park) saved the Ruwa river from pollution by preserving and protecting an open space along its edges (Muzorewa, 2017: 131). The open space left by ZB preserved the Ruwa river's ecological system by keeping human activities that caused pollution away from the river. Ruwa was also squatter free. Private security together with the Town Council security made the town impenetrable by squatters on private property. This improved the aesthetic value of the area while simultaneously preserving the ecological environment. The town being established by private entities, therefore, became exclusive.

\section{CONCLUSION}

The article concludes that the contribution and role played by PLDCs in urban development in postcolonial Zimbabwe with reference to Ruwa town was immense. It finds that, apart from facilitating the establishment of low- and high-density residential suburbs, developer companies contributed to the development of industrial and commercial areas, in spite of the ravages of an unremitting economic crisis in Zimbabwe that had the deleterious impact of hindering the industrialisation of the country. It provides a useful insight into these development issues in a unique situation. Some developers significantly facilitated the development of the built environment during the independence era by building residential suburbs in the town, while others developed industrial and commercial areas. It is evident that all the PLDCs, in a unique Zimbabwean case of non-direct government investment in postcolonial urban growth, developed off-site and supporting infrastructure which included roads, sewerage and water reticulation systems. In order to satisfy all the public infrastructure needs of the town, the PLDCs reserved land for the development of public and community amenities such as education, health institutions, and recreational facilities, which filled an important social role.

In a country beset by an un-abating economic crisis, the endowment fees paid by the private developers became one of the Local Authority's major revenue sources. Endowments, which were paid in the form of land, significantly eliminated the Council's land scarcity predicament by providing the required land. The endowments that were paid in cash to a certain extent allayed the cash woes of the Ruwa Town Council - a factor that 
eased the administrative costs of the Council during the crisis. Invariably, the permit system guaranteed urban council administration and control. For example, it was only after the issuing of a certificate of compliance to the PLDCs that the Local Authority took over the administration of off-site infrastructure and public amenities such as toilets, market places, open spaces, buffer zones, and sporting fields. This increased council-owned premises in the area, since the Council could not afford to build the facilities itself, because it did not have the money.

However, although the PLDCs' role in developing Ruwa was remarkable, the article demonstrated that it was not always positive as in some suburbs such as Tawona Park, Fairview Park, Cranbrook and Barochit, the development of off-site infrastructure was slow and, in other parts, it was incomplete. Economic challenges sometimes compromised the quality of PLDC-developed infrastructure; hence, developer companies failed to meet the required standards set by the urban planning authorities as stipulated in the land development permit. Notwithstanding the shortcomings of PLDCs, the companies still carried an important economic, social and infrastructural responsibility and, without them, the area would not have developed into the sprawling town it was by 2015 . The postcolonial State's acquiescence to draw on the services provided by PLDCs illustrates that the companies were, therefore, effective instruments in ensuring the success of the liberal urban development strategy adopted by the local town planners in spite of their shortcomings. Hence, the embryonic town of Ruwa is simultaneously an example and an exception as one of the few success stories of post-independence urban planning in Zimbabwe in a time of un-abating economic crisis.

\section{REFERENCES}

CSO (CENTRAL STATISTICAL OFFICE). 2014. Population Unit. Harare: Central Statistical Office.
CHEATER, A.P. 1986. Social anthropology: An alternative introduction. Gweru: Mambo Press.

CHIGARA, B., MAGWARO-NDIWENI, L., MUDZENGERERE, F. \& NCUBE, A. 2013. An analysis of the effects of piecemeal planning on development of small urban centres in Zimbabwe: Case study of Plumtree. Journal of Sustainable Development in Africa, 15(2), pp. 27-40.

CHIRISA, I. 2013. Housing and stewardship in peri-urban settlements in Zimbabwe: A case study of Ruwa and Epworth. Ph.D. thesis. University of Zimbabwe.

DAVISON, C.A. 2005. Urban governance and the effective delivery and management of infrastructure services in urban areas in Zimbabwe. (An appraisal of water and sewerage services delivered in Ruwa, Harare).

ECONOMICS HELP. 2018.

Hyperinflation in Zimbabwe. [online]. Available at: <http://www.economicshelp. org.> [Accessed: 15 June 2018].

DING, C. \& LICHTENBERG, E. 2009. Local officials as land developers: Urban spatial expansion in China. Journal of Urban Economics, 66(1), pp. 57-64. DOI: https://doi.org/10.1016/j. jue.2009.03.002

FOLLADOR, D., DUARTE, F. \& CARRIER, M. 2018. Informal institutions and path dependence in urban planning: The case of Curitiba, Brazil. Journal of Urban Affairs, pp. 1-20. DOI: 10.1080/07352166.2018.1495040

GOZ (GOVERNMENT OF ZIMBABWE). 1996. Regional, Town and Country Planning Act, Chapter 29:12. Harare: Government Printers.

KING, L.O. \& LOWE, J.S. 2018. We want to do it differently: Resisting gentrification in Houston's Northern Third Ward. Journal of Urban Affairs, 40(8), pp. 1161-1176. DOI: 10.1080/07352166.2018.1495039

MARONGWE, N., MUKOTO, S. \& CHATIZA, K. 2011. Scoping study: Governance of urban land markets in Zimbabwe. Prepared for Urban Land Mark by the Applied Social Sciences Trust, University of Zimbabwe, pp. 1-118.

MASHONALAND HOLDINGS PRIVATE LIMITED. 2014. Company profile. [online]. Available at: <http://www. masholdings.co.zw. $>$ [Accessed: 19 October 2018].
MIFAFTAB, F. 2004. Private-public partnerships: The Trojan horse of neo-liberal development. Journal of Planning Education and Research, 24(1), pp. 89-101. DOI: https://doi. org/10.1177/0739456X04267173

MLAMBO, A.S. 1997. The economic structural adjustment programme: The case of Zimbabwe. Harare: University of Zimbabwe Publications.

MOSZORO, M. \& KRZYZANOWSKA, M. 2011. Implementing public-private partnership in municipalities. Spain: IESE Business School, University of Navarra. DOI: https://doi. org/10.2139/ssrn.1679995

MUZOREWA, T.T. 2017. The role of private land developers in urban development in Zimbabwe: The case of Ruwa town, 1980-2015. Unpublished Ph.D. thesis. Zimbabwe: Midlands State University.

NAZ (NATIONAL ARCHIVES OF ZIMBABWE), 38971. 1995. Ministry of Local Government Rural and Urban Development: Department of Physical Planning pamphlet.

NYANDORO, M. 2018. Citizen engagement circumvented: An analysis of liquid waste information/knowledge, control and environmental policy perspectives in Harare, Zimbabwe. Environment and History, Fast track article, online, 25 July 25 . DOI: https://doi.org/10.3197/09673401 8X15254461646431

NYANDORO, M. \& MUZOREWA, T.T. 2017. Transition from growth point policy to liberal urban development in Zimbabwe: The emergence of Ruwa town, 1980-1991. The Journal for Transdisciplinary Research in Southern Africa, 13(1), pp. 1-10. https://doi. org/10.4102/td.v13i1.426

ODERO, K. 2003. Local authorities' response to restructuring. Paper presented at the $39^{\text {th }}$ ISoCaRP Congress, 17-22 October, Cairo, Egypt.

PALMER ASSOCIATES PRIVATE LIMITED. 1996. Proposed developments of Lot 1 of Cranbrook of Ruwa. Unpublished manuscript.

RUWA TOWN COUNCIL. 1996a. File C14. Certificate of Compliance to Mashonaland Holdings. Unpublished manuscript.

RUWA TOWN COUNCIL. 1996b. Certificate of Compliance to Mashonaland Holdings Private Limited. Unpublished manuscript. 
RUWA TOWN COUNCIL. 2001a.

Permit for the subdivision of land: $J$ and $\mathrm{H}$ Enterprises. Unpublished manuscript.

RUWA TOWN COUNCIL. 2001b.

File CAA. Subdivision of Inverangus of Sebastopol. Letter from RLB to the Provincial Officer Department of Physical Planning, 2 May.

RUWA TOWN COUNCIL. 2003a.

File CPP. Certificate of Compliance to Zimre from Ruwa Local Board. Unpublished manuscript.

RUWA TOWN COUNCIL. 2003b.

Certificate of Compliance to $\mathrm{J}$ and $\mathrm{H}$ Enterprises Private Limited from Ruwa Local Board. Unpublished manuscript.

RUWA TOWN COUNCIL. 2004.

File 1CII. Certificate of compliance to Chipukutu Properties (Pvt) Ltd. Unpublished manuscript.

RUWA TOWN COUNCIL. 2006a. File CPP. Zimre institutional development. Unpublished manuscript.

RUWA TOWN COUNCIL. 2006b.

Correspondence letter from Intermarket to A. Mujuru of Ruwa Local Board, 19 April.

RUWA TOWN COUNCIL. 2006c. File $\mathrm{C} / 17$. Information used at a meeting held between the Permanent Secretary for Local Government, Public Works and Urban Development, Ruwa Local Board and three developers: Tawona portion of Galway Estate, Lot 1 of Cranbrook, Sebassa and their respective beneficiaries' representatives, February.

RUWA TOWN COUNCIL. 2011. Ruwa Town Council at a glimpse. Report from the Town Secretary.

THE HERALD. 2007. Ruwa Local Board turns 16. The Herald, 23 October.

VAN DER VEEN, M. 2009. Contracting for better places: A relational analysis of development agreements in urban development projects. Amsterdam: IOS Press.

WEI, C., TAUBENBOCK, H. \& BLASCHKE, T. 2017. Measuring urban agglomeration using a city-scale dasymetric population map: A study in the Pearl River Delta, China. Habitat International, 59, pp. 32-43. DOI: https:// doi.org/10.1016/j.habitatint.2016.11.007 